\title{
Religiosity and spirituality in patients with epilepsy
}

\author{
Religiosidade e espiritualidade em pacientes com epilepsia \\ Isadora Barazzetti RIGON', Gabriel de Almeida CALADO', Lucas Savaris LINHARES', Pietro Lentz Martins \\ CANTU', Jorge Luis Wollstein MORITZ², Peter WOLF ${ }^{2,3,4}$, Katia LIN'2,3
}

\begin{abstract}
Religiosity and spirituality (R/S) are widely regarded as important allies against illness and suffering in general. Findings in temporal lobe epilepsy (TLE) suggest the temporal lobe as the anatomical-functional basis of religious experiences. Both R/S are relevant in patients with epilepsy (PWE) since epilepsy can lead to psychosocial issues for a significant portion of patients and their families. Objective: To investigate R/S in PWE, as well as the impact of different epileptic syndromes on patients' R/S. Methods: One hundred PWE and 50 healthy volunteers matched for age, sex and educational level were submitted to an interview, as well as three previously validated questionnaires: Index of Core Spiritual Experience (INSPIRIT-R), Hospital Anxiety and Depression Scale (HADS), and the Quality of Life in Epilepsy Inventory (QOLIE-31). Results: PWE's and control's mean ages were $35.9 \pm 12.4 \mathrm{vs}$. $36.3 \pm 18.1$ years, mean schooling was $8.9 \pm 3.7$ vs. $10.1 \pm 4.2$ years. The mean age of epilepsy onset was $14.5 \pm 12.1$ and monthly frequency of seizures was $5.9 \pm 12.6$. INSPIRIT-R's scores were not statistically significantly different between patients and controls ( $3.0 \pm 0.8$ vs. $3.0 \pm 0.8$ ); however, INSPIRIT-R's scores were significantly higher in TLE patients when compared with other epilepsy syndromes (3.2 \pm 0.7 vs. $2.8 \pm 0.9 ; p=0.04)$. Conclusion: Temporal lobe epilepsy patients have higher levels of R/S.
\end{abstract}

Keywords: Epilepsy, temporal lobe; quality of life; spirituality.

\section{RESUMO}

Religiosidade e espiritualidade (R/E) são geralmente consideradas importantes aliadas no enfrentamento de doenças e sofrimento. Estudos na epilepsia do lobo temporal (ELT) sugerem que o lobo temporal é a base anatômico-funcional de experiências religiosas. Além disso, R/E têm impacto na vida de pacientes com epilepsia (PCE), uma vez que a epilepsia frequentemente está associada a distúrbios psicossociais em pacientes e seus familiares. Objetivo: Investigar R/E em PCE, bem como o impacto de diferentes síndromes epilépticas na R/E dos pacientes. Método: Cem PCE e 50 voluntários saudáveis pareados por idade, sexo e nível educacional foram submetidos a uma entrevista, bem como três questionários previamente validados: Index of Core Spiritual Experience (INSPIRIT-R), Hospital Anxiety and Depression Scale (HADS), e Quality of Life in Epilepsy Inventory (QOLIE-31). Resultados: As médias de idade de PCE e controles foram de $35,9 \pm 12,4$ vs. 36,3 \pm 18,1 anos, com escolaridade média de 8,9 $\pm 3,7$ vs. 10,1 \pm 4,2 anos. A idade média do início da epilepsia foi de 14,5 $\pm 12,1$ e a frequência de crises mensais foi de 5,9 $\pm 12,6$. Os escores do INSPIRIT-R não foram estatisticamente diferentes entre os pacientes e controles (3,0 \pm 0,8 vs. 3,0 \pm 0,8); entretanto, os escores do INSPIRIT-R foram significativamente maiores em pacientes com ELT quando comparados com outras síndromes epilépticas ( $3,2 \pm 0,7$ vs. $2,8 \pm 0,9 ; p=0,04)$. Conclusão: Pacientes com epilepsia do lobo temporal possuem níveis mais altos de religiosidade e espiritualidade.

Palavras-chave: Epilepsia do lobo temporal; qualidade de vida; espiritualidade.

Religiosity and spirituality are widely regarded as important allies against illness and suffering in general. Currently, there is an increasing consensus on the importance of these factors for patients' quality of life $\mathrm{e}^{1,2,3}$.
Religiosity can be defined as the degree of participation or adherence in which individuals believe, follow and practice a religion. It represents the extent of one's faith in the existence of a supernatural power they believe imbued them

\footnotetext{
${ }^{1}$ Universidade Federal de Santa Catarina, Curso de Graduação em Medicina, Florianópolis SC, Brasil;

${ }^{2}$ Universidade Federal de Santa Catarina, Programa de Pós-Graduação em Ciências Médicas, Florianópolis SC, Brasil;

${ }^{3}$ Universidade Federal de Santa Catarina, Hospital Universitário, Departamento de Clínica Médica, Serviço de Neurologia, Florianópolis SC, Brasil;

${ }^{4}$ Danish Epilepsy Centre, Dianalund, Denmark.
}

Isadora Barazzetti Rigon (iD) https://orcid.org/0000-0002-8690-9340; Gabriel de Almeida Calado iD https://orcid.org/0000-0002-6177-2800; Peter Wolf (iD) https://orcid.org/0000-0003-2547-976X; Katia Lin (iD) https://orcid.org/0000-0002-5401-7524

Correspondence: Katia Lin; Departamento de Clínica Médica, Hospital Universitário Polydoro Ernani de São Thiago; Rua Prof. Maria Flora Pausewang s/n / 30 andar; Caixa Postal: 5199, Campus Universitário; 88040-900 Florianópolis SC, Brasil; E-mail: linkatia@uol.com.br

Conflict of interest: There is no conflict of interest to declare.

Support: CNPq, CAPES

Received 30 October 2018; Received in final form 12 January 2019; Accepted 11 February 2019. 
with a spiritual nature that continues to exist after death ${ }^{1,2,3,4}$. Spirituality, in turn, is seen as a human propensity to search for significance in life; it is a dynamic, personal, and experiential process, often addressed within the practice of a religious creed, and includes transcendence, purpose, and values that can be shared by people of different ethnic origins, cultures and religions ${ }^{1,2,3,5}$.

Previous studies among temporal lobe epilepsy (TLE) patients suggested that the temporal lobe could be the main anatomical processing center responsible for individuals' religiosity ${ }^{6,7,8}$. Religiosity and spirituality $(\mathrm{R} / \mathrm{S})$ can be relevant in patients with epilepsy (PWE) since their condition can lead to psychosocial issues for many patients and their families ${ }^{9,10,11,12,13,14}$.

Therefore, the purpose of this study is the investigation of R/S in PWE and within different epilepsy syndromes, the underlying hypothesis being that PWE, in particular with TLE, would have a distinct $\mathrm{R} / \mathrm{S}$ profile compared with healthy controls.

\section{METHODS}

\section{Subjects and structure of study}

An observational case-control study was conducted between August 2016 and March 2017 and 150 subjects were included. Of these, 100 consecutive patients had a definite diagnosis of epilepsy according to the International League Against Epilepsy (ILAE) criteria ${ }^{9,15}$. The diagnosis was based on clinical history and seizure semiology supported by electroencephalography (EEG) or video-EEG and magnetic resonance imaging (MRI) or computed tomography (CT) findings consistent with the diagnosis. All patients were on treatment with one or more standard antiepileptic drugs (AEDs). They were followed at the University Hospital of the Federal University of Santa Catarina (UFSC) Epilepsy Clinic for at least one year. The control group comprised 50 consecutive healthy volunteers matched for age, sex and educational level, recruited during the same period from the local community. The following exclusion criteria were adopted:

1) Individuals younger than 18 years;

2) Subjects with intellectual impairment that prevented them from understanding the questionnaires and the interview;

3) Subjects with either medical or surgical treatment resulting in complete seizure control for at least one year;

4) Subjects with psychogenic nonepileptic seizures.

\section{Procedure}

1) Patients were face-to-face interviewed for sociodemographic data (age, sex, occupation, marital status, schooling, socioeconomic status) and clinical data (age at onset, type and frequency of seizures, duration of epilepsy, AEDs and epileptic syndrome).
2) The patients' socioeconomic status was measured using the ABEP's (Brazilian Market Research Association) questionnaire for socioeconomic stratification criteria updated for 2016. This instrument attributes different relative socioeconomic classifications to individuals based on access to basic utilities, material possessions, and level of education ${ }^{16}$.

3) Application of the Index of Core Spiritual Experience (INSPIRIT-R) $^{17}$ for quantification of $\mathrm{R} / \mathrm{S}$. This instrument contains seven items, the seventh consisting of a list of 12 types of religious experiences, on which the patient is asked whether he/she experienced any of them and, if so, whether or not this strengthened his/her belief in God, and/or convinced him/her of God's existence. Responses were recorded on a 1-4 scale. Higher scores indicate higher R/S.

4) Application of the Hospital Anxiety and Depression Scale $(\mathrm{HADS})^{18}$ to determine anxiety and depression. This scale has 14 items, seven of which are for anxiety assessment (HADS-A) and seven for depression (HADS-D). After calculating the score of each sub-scale (0-21), both were summed up in order to obtain the total score (0-42). Scores over 7 in each sub-scale indicate anxiety or depression.

5) Application of the Quality of Life in Epilepsy Inventory (QOLIE-31) $)^{19,20}$ to determine quality of life. This is a globally used epilepsy-specific instrument with seven domains: worry about seizures, overall quality of life, emotional wellbeing, energy-fatigue, cognitive functioning, medication effects, and social functioning. The overall score ranges from 1 to 100 . Higher scores indicate higher quality of life.

The PWE were tested with all the above procedures, and the control group (CG) with procedures 1, 2, and 3. These instruments have been previously validated in Brazil $^{21,22,23}$.

\section{Data analysis}

Statistical analysis was performed using GNU PSPP for Windows, STATISTICA ${ }^{\bullet}$ Ultimate Academic version, and Microsoft Excel ${ }^{\odot}$ software package for Windows, 2014. Descriptive analysis was made to characterize the sample. Quantitative variables were expressed as mean \pm standard deviation (SD) and qualitative variables were expressed as frequency and percentage values. Two-tailed Student's t-test was applied to compare continuous variables, while Fisher's exact test ( $2 \times 2$ contingency tables) or Pearson's Chi square analysis ( $3 \times 2$ contingency tables) was used to compare qualitative data and frequencies of occurrence. A p-value $<0.05$ was considered to be statistically significant.

\section{Ethics}

This study was carried out in accordance with the Code of Ethics of the World Medical Association (Declaration of Helsinki) and was only started after approval by the UFSC Ethics Committee for Human Research ${ }^{24}$. All subjects signed an informed consent form and voluntarily agreed to participate. 


\section{RESULTS}

Sociodemographic variables for patients and controls are listed in Table 1. The patients' age ranged from 18 to 66 years, similar to the controls, who had an age range of 19-83 years. Although PWE and controls had similar years of schooling, they differed with regard to socioeconomic status, in which most patients were in ABEP class $\mathrm{C}$, while the majority of controls were in class $\mathrm{B}$.

PWE had an average age of disease onset during adolescence and a mean of two decades of epilepsy duration, the majority of patients were using two AEDs, and an average monthly frequency of epileptic seizures of $5.9 \pm 12.6$.

In terms of the different epilepsy syndromes, $72 \%$ of patients had focal epilepsies, mainly (63\%) with TLE. The remaining included patients with idiopathic generalized epilepsies and some cases not clearly belonging to any definite syndrome. For statistical analysis, they were grouped together with the focal extratemporal epilepsies as "other".
With regard to R/S, PWE had similar INSPIRIT-R scores to the controls, with both groups having an average of 3.1 on a scale that quantitatively estimates $\mathrm{R} / \mathrm{S}$ ranging from 1 (minimum R/S) to 4 (maximum R/S). Comparing TLE patients with other PWE and controls, the TLE group had a higher score on the INSPIRIT, which demonstrates a quantitatively higher degree of $\mathrm{R} / \mathrm{S}$ (Table 2).

Upon analyzing quality of life in PWE, those with TLE achieved similar scores to those of patients with other epilepsies on the QOLIE-31 scale, as shown in Table 2.

Anxiety and depression scores on the HADS scale showed no statistically significant difference between PWE and controls, though scores for the PWE group appeared slightly higher. Regarding epilepsy subtypes, patients with TLE likewise scored slightly lower for anxiety and depression, but the difference was not statistically significant (Table 2).

In terms of correlation between $\mathrm{R} / \mathrm{S}$ scores and clinicaldemographic variables (Table 3), in the control group no statistically significant correlation was found between the

Table 1. Sociodemographic characteristics of participants.

\begin{tabular}{|c|c|c|c|}
\hline Sociodemographic variables & $\operatorname{PWE}(n=100)$ & Controls $(n=50)$ & p-value \\
\hline \multicolumn{4}{|l|}{ Sex } \\
\hline Male & $45(45.0 \%)$ & $16(32.0 \%)$ & \multirow{2}{*}{0.128} \\
\hline Female & $55(55.0 \%)$ & $34(68.0 \%)$ & \\
\hline Age, mean \pm SD & $35.9 \pm 12.4$ & $36.3 \pm 18.1$ & 0.894 \\
\hline Years of schooling, mean \pm SD & $8.9 \pm 3.7$ & $10.1 \pm 4.2$ & 0.081 \\
\hline \multicolumn{4}{|l|}{ Education level } \\
\hline Incomplete Elementary School & $30(30.0 \%)$ & $13(26.0 \%)$ & \multirow{6}{*}{0.051} \\
\hline Complete Elementary School & $12(12.0 \%)$ & $1(2.0 \%)$ & \\
\hline Incomplete High School & $9(9.0 \%)$ & $3(6.0 \%)$ & \\
\hline Complete High School & $30(30.0 \%)$ & $10(20.0 \%)$ & \\
\hline Incomplete Superior Education & $12(12.0 \%)$ & $22(44.0 \%)$ & \\
\hline Complete Superior Education & $7(7.0 \%)$ & $1(2.0 \%)$ & \\
\hline \multicolumn{4}{|l|}{ Socioeconomic status* } \\
\hline A & $3(3.0 \%)$ & $3(6.0 \%)$ & \multirow{4}{*}{$0.007 * \star$} \\
\hline B & $32(32.0 \%)$ & $26(52.0 \%)$ & \\
\hline C & $58(58.0 \%)$ & $20(40.0 \%)$ & \\
\hline $\mathrm{D} / \mathrm{E}$ & $7(7.0 \%)$ & $1(2.0 \%)$ & \\
\hline
\end{tabular}

PWE: patients with epilepsy; SD: standard deviation; *ABEP socioeconomic stratification criteria updated for 2016; patients and controls were not paired with regard to socioeconomic status. ${ }^{*}$ Statistically significant $p$ value.

Table 2. Participants' scores in scales/questionnaires.

\begin{tabular}{|c|c|c|c|c|c|c|}
\hline \multirow{2}{*}{ Variables } & \multicolumn{2}{|c|}{ INSPIRIT-R } & \multicolumn{2}{|c|}{ HADS } & \multicolumn{2}{|c|}{ QOLIE-31 } \\
\hline & Mean \pm SD & $p$-value & Mean \pm SD & $p$-value & Mean \pm SD & $p$-value \\
\hline Control $(n=50)$ & $3.1 \pm 0.8$ & 0.904 & $12.6 \pm 6.6$ & 0.422 & --- & --- \\
\hline $\operatorname{PWE}(n=100)$ & $3.1 \pm 0.8$ & & $13.6 \pm 7.7$ & & --- & --- \\
\hline TLE $(n=63)$ & $3.3 \pm 0.7$ & $0.041 *$ & $13.5 \pm 7.9$ & 0.776 & $58.4 \pm 16.1$ & 0.755 \\
\hline Other $(n=37)$ & $2.9 \pm 0.9$ & & $13.9 \pm 7.6$ & & $59.7 \pm 20.7$ & \\
\hline
\end{tabular}

PWE: patients with epilepsy; SD: standard deviation; TLE: temporal lobe epilepsy. *Statistically significant p value. 
Table 3. Correlations - scores/scales vs. clinical-demographical variables.

\begin{tabular}{|c|c|c|c|c|c|c|}
\hline \multirow{2}{*}{ Variables } & \multicolumn{2}{|c|}{ INSPIRIT-R } & \multicolumn{2}{|c|}{ HADS } & \multicolumn{2}{|c|}{ QOLIE-31 } \\
\hline & $r$ & $p$-value & r & $p$-value & r & p-value \\
\hline \multicolumn{7}{|l|}{ PWE } \\
\hline Age & +0.32 & $0.001 *$ & +0.06 & 0.570 & -0.07 & 0.500 \\
\hline Schooling (years) & -0.04 & 0.720 & +0.06 & 0.559 & -0.11 & 0.279 \\
\hline Number of AEDs & +0.06 & 0.571 & +0.13 & 0.203 & -0.08 & 0.431 \\
\hline Duration of epilepsy & +0.25 & $0.011 *$ & +0.06 & 0.542 & -0.07 & 0.510 \\
\hline Seizure frequency (per month) & +0.04 & 0.754 & +0.08 & 0.528 & -0.18 & 0.129 \\
\hline \multicolumn{7}{|l|}{ Controls } \\
\hline Age & +0.21 & 0.151 & -0.35 & $0.011 *$ & --- & --- \\
\hline Schooling (years) & -0.16 & 0.275 & +0.28 & $<0.001 *$ & --- & --- \\
\hline
\end{tabular}

degree of $\mathrm{R} / \mathrm{S}$, age and years of schooling. In the epilepsy group, however, there was a statistically significant correlation between $\mathrm{R} / \mathrm{S}$ and age, such that older patients had higher R/S. There was also a significant correlation between $\mathrm{R} / \mathrm{S}$ in PWE and total years with epilepsy, such that patients living with epilepsy for a longer period had higher R/S. There was no correlation between R/S and years of schooling, number of AEDs in use and monthly frequency of epileptic seizures in PWE.

Correlations between scales/scores of R/S, quality of life and anxiety and depression are shown in Table 4. Although there were no significant correlations between the INSPIRIT-R scale and HADS or QOLIE-31, there was a negative correlation between HADS and QOLIE-31 in PWE, suggesting that patients with more anxiety and depression have lower quality of life.

\section{DISCUSSION}

\section{$\mathrm{R} / \mathrm{S}$ in patients with epilepsy compared with controls}

INSPIRIT-R means were similar between PWE and healthy controls. This could be due to the already considerably high levels of $\mathrm{R} / \mathrm{S}$ found in the Brazilian population that could obfuscate minor differences between different population subsets. In a recent transcultural study of locus of control in PWE comparing Brazilians and Lithuanians, the INSPIRIT-R scores differed strongly ( $3.11 \pm 0.87$ vs. $2.45 \pm 0.72$, $\mathrm{p}<0.0001$ ), in Lithuania likewise without significant difference from healthy controls ${ }^{25}$.

Our results deviate from the previous literature, which compared only measures of religiosity between epilepsy and control groups, without consideration to the wider context of spirituality. Tedrus et al. found that PWE $(n=159)$ had a higher health-related religiosity score when compared to a control group $(\mathrm{n}=50)$ using the Duke Religion Index ${ }^{26}$. This instrument, however, limits the variable of religiosity, assessing it purely as pertaining to health. Notwithstanding this,
Table 4. Correlations between scores/scales.

\begin{tabular}{lcc}
\hline Scores/Scales & $r$ & $p$-value \\
\hline PWE & & \\
\hline INSPIRIT-R vs. HADS & +0.07 & 0.457 \\
INSPIRIT-R vs. QOLIE-31 & +0.07 & 0.507 \\
Controls & & \\
\hline HADS vs. QOLIE-31 & -0.65 & $<0.001 *$ \\
INSPIRIT-R vs. HADS & -0.12 & 0.410 \\
\hline
\end{tabular}

PWE: patients with epilepsy; r: Pearson's correlation coefficient; *Statistically significant $\mathrm{p}$ value.

Tedrus et al., in another study, did not find a significant association between spirituality in PWE $(\mathrm{n}=196)$ when compared with controls $(n=66)$, corroborating our findings ${ }^{27}$.

\section{$\mathrm{R} / \mathrm{S}$ and the temporal lobe}

In a comparative analysis between TLE and other epilepsies, we found R/S means that were significantly higher in the TLE group, supporting the hypothesis that the temporal lobe could be the main anatomical processing center responsible for individuals' religiosity ${ }^{6,7,8}$.

\section{R/S and social-demographic factors}

No correlation was found between INSPIRIT-R, age and years of schooling within the controls, which suggests that those variables should not influence general individuals' $R / S$. In the epilepsy group, however, older patients had higher R/S, while years of schooling did not correlate with $\mathrm{R} / \mathrm{S}$. These findings disagree with those of Tedrus et al., also undertaken in Brazil, which suggest that spirituality in PWE is associated with fewer years of schooling ${ }^{27}$.

\section{R/S and clinical factors in epilepsy}

Patients with longer duration of epilepsy had higher scores on INSPIRIT-R. As the correlation between age and INSPIRIT-R was not observed in the controls, our finding may evidence some form of disease-related coping. It happens when people 
turn to R/S as a means of dealing with stress or problems in general. Depending on the way it is used, coping can be both positive - for example, when someone draws upon faith for resilience in the face of an obstacle in life - or negative - when one justifies their suffering as being warranted in light of some divine punishment. Tedrus et al. also found significant associations between coping and clinical aspects of epilepsy: while disease duration was associated with positive coping, frequency of seizures and earlier disease onset were both associated with negative coping mechanisms ${ }^{5}$.

In that vein, PWE in our study are probably using positive forms of coping as long as their disease is active, facing epilepsy as a barrier that must be overcome. Health professionals need to consider $\mathrm{R} / \mathrm{S}$, as well as the coping mechanisms derived from it, as potential factors to foster appropriate intervention on epilepsy care. In some PWE with higher R/S - especially among older ones and those with longer histories of epilepsy - negative coping strategies might be more prevalent, possibly interfering in patients' treatment response $\mathrm{e}^{14}$.

\section{R/S and quality of life}

INSPIRIT-R scores were not correlated with QOLIE-31, but PWE with lower levels of anxiety and/or depression had better scores on QOLIE-31. Additionally, patients with TLE obtained similar scores as those with other epilepsy subtypes on the QOLIE-31 scale.

A recent study undertaken in South Korea with 232 PWE found that lower levels of religiosity were linked to increased levels of anxiety and depression. However, this study again did not take into consideration the component of spirituality. Furthermore, the study evaluated high-functioning PWE, given that $85 \%$ of them had a high school level of education (versus only $49 \%$ from our sample). As such, their findings might not be readily generalizable to PWE in most developing countries ${ }^{28}$.

Giovagnoli et al. found an association between spirituality and quality of life in patients with focal epilepsy ${ }^{29}$. These results, however, were obtained comparing patients with different epilepsy subtypes in an attempt to explain their findings of PWE of similar severity, without comparison to control groups.

Finally, Tedrus et al. recently conducted a study in Brazil with 209 individuals (159 with epilepsy and 50 controls) in which - like in our study - no association was found between $\mathrm{R} / \mathrm{S}$ and quality of life ${ }^{26}$.

\section{Limitations and future perspectives}

This study compared R/S quantitatively between individuals with and without epilepsy. Patients' specific religious denominations, however, were not considered. Future studies should search for distinctions between different religions' performances on the INSPIRIT-R. In addition, the group of "other epilepsies" is a rather heterogeneous pool including subgroups that were too small to be analyzed separately but for which different relations could exist.

Specific religious and/or spiritual experiences patients might have had during (ictal), after (postictal) or in between (interictal) seizures were not explored in this study. Despite controversy in using epilepsy as a model to explain such experiences, a recent review of the literature points to TLE as having an important influence on religious and literature history, given that a considerable number of important religious figures including prophets, saints and even cult founders have had experiences very much akin to those of modern-day patients suffering from seizures in $\mathrm{TLE}^{30}$. Religious connotations - such as seizures being described as a punishment for sins, or even being considered a sign of prophetic abilities - are a primordial constituent part of the sociocultural context of epilepsy and can be observed in literature by means of religious metaphors ${ }^{31}$. There is also a growing body of clinical and historical evidence dating back 150 years linking epilepsy in general to religious experiences in patients in ictal, postictal and interictal states ${ }^{32}$.

Although this study found significant associations between R/S and TLE, further research is needed with larger cohorts to identify the impact of $\mathrm{R} / \mathrm{S}$ on physical and mental health and to determine how these variables could influence clinical outcomes and quality of life in PWE.

In conclusion, there were no differences on $\mathrm{R} / \mathrm{S}$ of $\mathrm{PWE}$ compared with controls; TLE patients, however, were found to have higher levels of religiosity and spirituality than PWE with other epilepsy subtypes, supporting the theory that the temporal lobe could be structurally or physiologically associated with the experience of religiosity and spirituality in the human mind.

\section{ACKNOWLEDGMENTS}

The authors: KL holds a CNPq (Brazilian Council for Scientific and Technologic Development, Brazil) PQ2 Research Fellowship (Process No. 304936/2017-0), IBR had financial support from the Institutional Program of Scientific Initiation from CNPq-PIBIC/UFSC, and PW holds a Special visiting researcher - Fellowship in Brazil - Science Without Borders Program - Project MEC/MCTI/CAPES/CNPq/FAPs Process No. 88881.030478/2013-01 - from CAPES.

\section{References}

1. Mishra SK, Togneri E, Tripathi B, Trikamji B. Spirituality

and religiosity and its role in health and diseases.

J Relig Health. 2017 Aug;56(4):1282-301.

https://doi.org/10.1007/s10943-015-0100-z
2. Park CL, Masters KS, Salsman JM, Wachholtz A, Clements AD, Salmoirago-Blotcher E, et al. Advancing our understanding of religion and spirituality in the context of behavioral medicine. J Behav Med. 2017 Feb;40(1):39-51. https://doi.org/10.1007/s10865-016-9755-5 
3. Fleck MP, Borges ZN, Bolognesi G, da Rocha NS. [Development of WHOQOL spirituality, religiousness and personal beliefs module]. Rev Saude Publica. 2003 Aug;37(4):446-55. Portuguese. https://doi.org/10.1590/S0034-89102003000400009

4. Levin JS, Chatters LM. Research on religion and mental health: an overview of empirical findings. In: Koenig HG, editor. Handbook of religion and mental health. Cambridge: Academic Press; 1998. pp. 33-50. https://doi.org/10.1016/B978-012417645-4/50070-5

5. Tedrus GM, Fonseca LC, Magri FP, Mendes PH. Spiritual/religious coping in patients with epilepsy: relationship with sociodemographic and clinical aspects and quality of life. Epilepsy Behav. 2013 Sep;28(3):386-90. https://doi.org/10.1016/j.yebeh.2013.05.011

6. Dewhurst K, Beard AW. Sudden religious conversions in temporal lobe epilepsy. Br J Psychiatry. 1970 Nov;117(540):497-507. https://doi.org/10.1192/bjp.117.540.497

7. Ozkara C, Sarý H, Hanoğlu L, Yeni N, Aydoğdu I, Ozyurt E. Ictal kissing and religious speech in a patient with right temporal lobe epilepsy. Epileptic Disord. 2004 Dec;6(4):241-5.

8. Trimble M, Freeman A. An investigation of religiosity and the Gastaut-Geschwind syndrome in patients with temporal lobe epilepsy. Epilepsy Behav. 2006 Nov;9(3):407-14. https://doi.org/10.1016/j.yebeh.2006.05.006

9. Fisher RS, Acevedo C, Arzimanoglou A, Bogacz A, Cross JH, Elger CE, et al. ILAE official report: a practical clinical definition of epilepsy. Epilepsia. 2014 Apr;55(4):475-82. https://doi.org/10.1111/epi.12550

10. Hauser WA, Rich SS, Lee JR, Annegers JF, Anderson VE. Risk of recurrent seizures after two unprovoked seizures. N Engl J Med. 1998 Feb;338(7):429-34. https://doi.org/10.1056/NEJM199802123380704

11. Kwan P, Brodie MJ. Early identification of refractory epilepsy. N Engl J Med. 2000 Feb;342(5):314-9. https://doi.org/10.1056/NEJM200002033420503

12. Kwan P, Sander JW. The natural history of epilepsy: an epidemiological view. J Neurol Neurosurg Psychiatry. 2004 Oct;75(10):1376-81. https://doi.org/10.1136/jnnp.2004.045690

13. Leone MA, Giussani G, Nolan SJ, Marson AG, Beghi E. Immediate antiepileptic drug treatment, versus placebo, deferred, or no treatment for first unprovoked seizure. Cochrane Database Syst Rev. 2016 May;6(5):CD007144. https://doi.org/10.1002/14651858.CD007144.pub2

14. Lin CY, Saffari M, Koenig HG, Pakpour AH. Effects of religiosity and religious coping on medication adherence and quality of life among people with epilepsy. Epilepsy Behav. 2018 Jan;78(1):45-51. https://doi.org/10.1016/j.yebeh.2017.10.008

15. Thurman DJ, Beghi E, Begley CE, Berg AT, Buchhalter JR, Ding D, et al. Standards for epidemiologic studies and surveillance of epilepsy. Epilepsia. 2011 Sep;52 Suppl 7:2-26. https://doi.org/10.1111/j.1528-1167.2011.03121.x

16. Associação Brasileira de Empresas de Pesquisa - ABEP. Critério de classificação econômica Brasil 2016 [cited 2018 Oct 5]. Available from: https://doi.org/www.abep.org/criterio-brasil

17. Kass JD, Friedman R, Leserman J, Caudill M, Zuttermeister PC, Benson H. An Inventory of Positive Psychological Attitudes with potential relevance to health outcomes: validation and preliminary testing. Behav Med. 1991;17(3):121-9. https://doi.org/10.1080/08964289.1991.9937555
18. Zigmond AS, Snaith RP. The hospital anxiety and depression scale. Acta Psychiatr Scand. 1983 Jun;67(6):361-70. https://doi.org/10.1111/j.1600-0447.1983.tb09716.x

19. Cramer JA, Perrine K, Devinsky O, Bryant-Comstock L, Meador K, Hermann B. Development and crosscultural translations of a 31-item quality of life in epilepsy inventory. Epilepsia. 1998 Jan;39(1):81-8. https://doi.org/10.1111/j.1528-1157.1998.tb01278.x

20. Devinsky 0 . Clinical uses of the quality-of-life in epilepsy inventory. Epilepsia. 1993;34(s4 Suppl 4):S39-44. https://doi.org/10.1111/j.1528-1157.1993.tb05915.x

21. Veronez IS, Bicalho MA, Claudino LS, Walz R, Lin K. Crosscultural translation of the INSPIRIT-R for Brazil and its applicability among epilepsy patients. Arq Neuropsiquiatr. 2011;69(2b 2B):310-5. https://doi.org/10.1590/S0004282X2011000300008 PMID:21625756

22. Botega NJ, Bio MR, Zomignani MA, Garcia C Jr, Pereira W. Mood disorders among medical in-patients: a validation study of the hospital anxiety and depression scale (HAD). Rev Saude Publica. 1995;29(5):359-63. Portuguese. https://doi.org/10.1590/S0034-89101995000500004

23. Silva TI, Ciconelli RM, Alonso NB, Azevedo AM, WestphalGuitti AC, Pascalicchio TF, et al. Validity and reliability of the Portuguese version of the quality of life in epilepsy inventory (QOLIE-31) for Brazil. Epilepsy Behav. 2007 Mar;10(2):234-41. https://doi.org/10.1016/j.yebeh.2006.08.022

24. World Medical Association - WMA. World Medical Association Declaration of Helsinki: ethical principles for medical research involving human subjects. JAMA. 2013 Nov;310(20):2191-4. https://doi.org/10.1001/jama.2013.281053

25. Moritz JL, Mameniškienè R, Rimšienè J, Budriūnienè A, de Almeida Calado G, Rigon IB, et al. Control perceptions in epilepsy: A transcultural case-control study with focus on auras. Epilepsy Behav. 2018 Nov;88(1):130-8. https://doi.org/10.1016/j.yebeh.2018.09.005

26. Tedrus GM, Fonseca LC, Fagundes TM, Silva GL. Religiosity aspects in patients with epilepsy. Epilepsy Behav. 2015 Sep;50(1):67-70. https://doi.org/10.1016/j.yebeh.2015.06.003

27. Tedrus GM, Fonseca LC, Höehr GC. Spirituality aspects in patients with epilepsy. Seizure. 2014 Jan;23(1):25-8. https://doi.org/10.1016/j.seizure.2013.09.005

28. Lee SA, Ryu HU, Choi EJ, Ko MA, Jeon JY, Han SH, et al. Associations between religiosity and anxiety, depressive symptoms, and wellbeing in Korean adults living with epilepsy. Epilepsy Behav. 2017 Oct;75(1):246-51. https://doi.org/10.1016/j.yebeh.2017.06.005

29. Giovagnoli AR, Meneses RF, Silva AM. The contribution of spirituality to quality of life in focal epilepsy. Epilepsy Behav. 2006 Aug;9(1):133-9. https://doi.org/10.1016/j.yebeh.2006.04.002

30. Nakken KO, Brodtkorb E. [Epilepsy and religion]. Tidsskr Nor Laegeforen. 2011 Jul;131(13-14):1294-7. Norwegian. https://doi.org/10.4045/tidsskr.10.1049

31. Wolf P. Epilepsy and metaphors in literature. Epilepsy Behav. 2016;57(Pt B):243-6. https://doi.org/10.1016/j.yebeh.2015.12.029

32. Devinsky O, Lai G. Spirituality and religion in epilepsy. Epilepsy Behav. 2008 May;12(4):636-43. https://doi.org/10.1016/j.yebeh.2007.11.011 